\title{
UPPSALA NATURAL RADIOCARBON MEASUREMENTS I
}

\author{
INGRID OLSSON
}

\author{
Uppsala Universitets Fysiska Institution, Uppsala, Sweden
}

The following list covers the samples measured at the Uppsala radiocarbon laboratory during 1957, when the measurements started, and 1958. Two samples of sediments have been excluded, as the origin of the material was doubtful.

The technique used was described previously by the author (1958). The pretreatment will be briefly described here. Foreign material, e.g. rootlets, is removed before the chemical treatment is started. Samples of wood and charcoal are usually boiled with dilute $\mathrm{HCl}$, washed with distilled water, boiled with dilute $\mathrm{NaOH}$, washed again, and then made slightly acid and dried in an oven. This treatment will remove carbonates and most of the humus. Samples such as peat and gyttja are not treated with hydroxide as a rule. The shells are washed with acid so that the outer parts will be removed. The bones have been treated with acid. the gas evolved has been used for an age determination, and the carbon dioxide produced by burning the residue has been used for a second measurement. The two fractions, organic and inorganic, have been compared, and. if the results are the same within the limits of error, the dates can be used. When the samples have been treated in another manner and this is of interest, it has been mentioned as a comment after the description.

The reference sample is ten tree rings from A.D. 1785 to 1795 . The tree, an elm, grew at Vårdsätra $\left(59^{\circ} 471 / 2^{\prime} \mathrm{N}\right.$ Lat, $17^{\circ} 37^{\prime} \mathrm{E}$ Long $)$, Uppsala, Sweden. The wood was boiled with a solution of sodium carbonate and sodium hydroxide, washed with distilled water, boiled with a solution of sodium bisulphite, washed again with distilled water, and dried in an oven.

All samples are compared, in respect to $\mathrm{C}^{14}$ activity, to the cellulose from the above-mentioned elm, but the ages of many of them, carbonates especially, are corrected for isotopic fractionation as explained below. The possibility that groundwater and surface sea water may contain much less $\mathrm{C}^{14}$ may have the result that the ages of e.g. algae and shells will be too high when measured with the radiocarbon method, compare Münnich (1957a), Craig (1954), Revelle and Suess (1957), and Rubin and Alexander (1958). The Uppsala reference sample corresponds in age to a time of minimum activity in the curve given by de Vries (1958). Measurements on international cross-check samples such as those submitted by Münnich will make it possible for radiocarbon laboratories to use the same time-scale.

The value 5570 years has been used for the half-life.

Most samples have been sent to Stockholm for an analysis of the $\mathrm{C}^{1: 3} / \mathrm{C}^{1: 2}$ ratio compared with the Uppsala reference sample. This standard has not yet been related to other standards. No corrections for the abundance of oxygen isotopes are applied. The deviation from the Uppsala standard is denoted by $\delta$ and is expressed in per mil:

$$
\delta=\left(\frac{\mathrm{R}_{\mathrm{x}}-\mathrm{R}_{\mathrm{u}}}{\mathrm{R}_{\mathrm{u}}}\right) \times 1000
$$

where $R_{x}$ and $R_{u}$ are the ratios $C^{13} / C^{12}$ for the sample and the reference sample 
respectively. Most sediments are rather light (enriched in $\mathrm{C}^{12}$ ) compared with what is expected from Craig (1953, 1954) and Wickman (1952). A formation of petroleum will lead to a low figure for the $\mathrm{C}^{13}$ content. When the final result is corrected for the $\mathrm{C}^{13}$ deviations, the $\delta$ value is always given in a comment. The correction in the net counting rate of $\mathrm{C}^{14}$ is twice the $\mathrm{C}^{13}$ deviation, or $-2 \delta$, which amounts to several percent in the case of carbonate samples. A $1 \%$ increase in the net counting rate for the sample corresponds to a decrease of 80 years in the age. The error in the $\mathrm{C}^{13} / \mathrm{C}^{12}$ ratio is $\pm 1 \%$.

The results given are expressed in years B.P. The errors given include the standard deviations $(\sigma)$ of the counted particles for the unknown sample, the reference sample, and the background sample, as well as the error in the $\delta$ values. When the activity is very low, so that $2 \sigma$ corresponds to a possibility of infinite age, $2 \sigma$ has been used instead of $\sigma$.

A few samples had to be diluted with $\mathrm{CO}_{2}$, from an old source to bring them to the normal working pressure of $3 \mathrm{~atm}$.

\section{ACKNOWLEDGMENTS}

The descriptions of the samples are based on information provided by those who were responsible for collecting and submitting them. Before the final manuscript was ready most contributors were kind enough to read the $\mathrm{draft}$ and suggest improvements, and sincere thanks are due to them.

The author wants to express her gratitude to the following students, who have helped her with the age determinations: Fil.kand. I. Karlén, Fil.kand. S. Lindgren, Fil.mag. G. Jonsson, Fil. mag. Gunborg Jansson, and Fil.kand. K. G. Segland. Special thanks are also due to Ingenjör R. Ryhage, Karolinska Institutet, Stockholm, for his kindness in making the $\mathrm{C}^{13} / \mathrm{C}^{12}$ determinations; to Prof. K. Siegbahn who has made it possible to do this work at the institute; and to the Wenner-Gren Foundation, which supported the laboratory during the first measurements, and Statens Naturvetenskapliga Forskningsråd, which has supported the laboratory since July 1, 1957.

\section{SAMPLE DESCRIPTIONS}

\section{GEOLOGIC SAMPLES}

\section{A. Mediterranean area}

\section{Levant series}

Saprolithic mud from deep-sea cores in the Levant. As the sediments were formed in the absence of oxygen, they may represent an interstadial formation. since vertical mixing will be prevented during a time of high rainfall and freshwater supply. These samples are the first ones in an investigation of the connection of these levels with the paleohydrology in the Eastern Mediterranean Sea. Comment: Rubin and Suess (1955) have made radiocarhon measurements at 3 levels of core $189\left(33^{\circ} 54^{\prime} \mathrm{N}\right.$ Lat, $28^{\circ} 29^{\prime} \mathrm{E}$ Long) : W-132, depth 10 to $20 \mathrm{~cm}, 17.200 \pm 500 ; \mathrm{W} \cdot 133$, depth 170 to $180 \mathrm{~cm},>32,000 ;$ W.148, depth 360 to $370 \mathrm{~cm},>32,000$. Coll. 1948 by the Swedish Albatross Expedition (Pettersson) ; subm. by E. Olausson, Uppsala Universitets MineralogiskGeologiska Institution. 
Core $194\left(34^{\circ} 48^{\prime}\right.$ N Lat, $23^{\circ} 29^{\prime} \mathrm{E}$ Long), depth 9 to $17 \mathrm{~cm}$; total length of core $721 \mathrm{~cm}$, depth in the sea $3000 \mathrm{~m}$, even bottom at the coring place but irregular around it. Comment: $\delta=0.0 \%$

U.64. Levant 194: 341 to 347

The same core as U-54, depth 341 to $347 \mathrm{~cm}$. Comment: $2 \sigma$ is used. $\delta=$ $+1.9 \%$.

U-63. Levant 190: 331 to 340

Core $190\left(33^{\circ} 54^{\prime} \mathrm{N}\right.$ Lat, $26^{\circ} 10^{\prime} \mathrm{E}$ Long $)$, depth 331 to $339.5 \mathrm{~cm}$; total length of core $938 \mathrm{~cm}$, depth in the sea $2900 \mathrm{~m}$, slightly irregular hottom with westward slope. Comment: $2 \sigma$ is used. $\delta=+2.1 \%$.

\section{U.30. Grotto del Tufo, Capri}

Fragments of charcoal from Grotto del Tufo $\left(40^{\circ} 33^{\prime} \mathrm{N}\right.$ Lat, $14^{\circ} 16^{\prime} \mathrm{E}$ Long), Capri, Italy. The charcoal was embedded in gray sand with gastropods and small bones of vertebrates, overlying a sequence of dark volcanic ash. The stratum, Norin Hor. 7, probably belongs to Horizon No. 4 in the section published by Kyrle (1946, 1947). Sediments from the Tyrrhenian Sea, which include layers of ash from the same volcanic eruptions, are described by Norin (1958). Coll. 1957 and subm. by Erik Norin, Uppsala Universitets Mineralogisk-Ceologiska Institution. Comment: diluted. $2 \sigma$ is used.

\section{Western Mediterranean Sea series}

Two carbonate samples (clay and shells) from core $21002\left(37^{\circ} 26^{\prime} \mathrm{N}\right.$ Lat, $1^{\circ} 5^{\prime} \mathrm{E}$ Long). The depth of the sea is $2782 \mathrm{~m}$. Coll. $1948 \mathrm{by}$ the Swedish Albatross Expedition (Pettersson); subm. by K. G. Eriksson, Uppsala Universitets Mineralogisk-Geologiska Institutions Kvartärgeologiska avdelning. Comment: as the samples may contain limestone dust carried by the wind from the Sahara, the given ages should be considered maximal ages.

U-25. $21002(96.5$ to 100$) \quad 11,780 \pm 160$

The sample was taken 96.5 to $100 \mathrm{~cm}$ from the top of the core. Comment: $\delta=+23.0 \%$.

U-39. $21002(45$ to 48$) \quad 10,380 \pm 120$

The sample was taken 45 to $48 \mathrm{~cm}$ from the top of the core. Comment: $\delta=+21.8 \%$.

\section{B. Iceland}

\section{U-2. Hornafjördur}

$6510 \pm 100$

Parvocaricetum peat (Carex, Salix, and Betula nana) from Stokksnes $164^{\circ} 15^{\prime} \mathrm{N}$ Lalt, $15^{\circ}\left(0^{\prime} \mathrm{W}\right.$ Long), Hormaljördur. Iceland. 210 to 225 ('m below the present surface (Hiller sampler, $3 \mathrm{~cm}$ diam). From tephra layers in the peat (down to about $90 \mathrm{~cm}$ ) one (an estimate that about $0.5 \mathrm{~m}$ of the top of the sequence is abraded. At 130 to $200 \mathrm{~cm}$ there were remains of Betula. The section goes down to bedrock, about $290 \mathrm{~cm}$ below the surface. According to a diatom analysis (Jónsson), the locality was above sealevel throughout the period of peat formation. The high-water level is now about $10 \mathrm{~cm}$ below the 
surface. The locality is described by Jónsson (1957). Coll. 1953 by Jón Jónsson, Uppsala Universitets Paleontologiska Institution; subm. by F. Hjulström, Uppsala Universitets Geografiska Institution. Comment: $\delta=-4.8 \%$.

\section{U-3. Landbrot}

Sandy peat at the farm Ytri-Dalbaer $\left(63^{\circ} 46^{\prime} \mathrm{N}\right.$ Lat, $18^{\circ} 7^{\prime} \mathrm{W}$ Long), Landbrot, Iceland. The sample was taken $50 \mathrm{~cm}$ above the lava, about $6 \mathrm{~m}$ below the present surface. An analysis indicates only freshwater diatoms. The locality is described by Jónsson (1958). Coll. 1953 by Jón Jónsson, Uppsala Universitets Paleontologiska Institution; subm. by F. Hjulström, Uppsala Universitets Geografiska Institution. Comment: Thoroddsen (1925) assumed the age of the lava to be about $1000 \mathrm{yr}$, and Thorarinsson (1955) believed it to be older than the settlement period, A.D. 874, to 930, but younger than A.D. 700 . $\delta=-0.1 \%$.

\section{Spitsbergen}

\section{Nordaustlandet series}

Driftwood and shells found at different levels and distances from the sea. The wood probably comes from Siberia (in no case have the tree species been determined as yet) and is very well preserved. Some of it may first have been deposited in the deltas on the northern coast of Siberia or elsewhere in Spitsbergen before it finally reached Nordaustlandet. The shells usually occur on raised beaches developed on the underlying till. Pumice (scoria) is also abundant on the raised beaches, and the wood often occurs at similar levels. The samples are the first in a series collected to determine the age of the beaches and the rate of land rise. All elevations are above mean sealevel. Coll. and subm. by W. Blake Jr., Department of Geology, Ohio State University, and Geografiska Institutet, Stockholms Högskola, Stockholm.

\section{U-33. Murchisonf jorden $1 \quad \mathbf{6 7 8 0} \pm 100$}

Wood from the west side of Kvalrosshalvøya $\left(79^{\circ} 59^{\prime} \mathrm{N}\right.$ Lat, $18^{\circ} 35^{\prime} \mathrm{E}$ Long); $2.0 \mathrm{~m}$ level, $7 \mathrm{~m}$ from the sea. Sample from the exposed part of a partly buried log. This level is near the lower pumice level. Coll. 1957. Comment: $\delta=0.0 \%$.

\section{U-34. Murchisonf jorden 2}

$1020 \pm 90$

Wood from the west side of Kralrosshalroya $179^{\circ} 59^{\prime} \mathrm{N}$ Lat. $18^{\circ} 35^{\prime} \mathrm{E}$ long) : $9.8 \mathrm{~m}$ level, $50 \mathrm{~m}$ from the sea. Sample from the buried part of a nearly huried low. This level is the upper pumice level. Coll. 1957. Comment: $\delta=$ $0.0 \%$.

\section{U.38. Murchisonf jorden 7}

$7830 \pm 120$

Wood from the west side of Kralrossinalvoya $\left(79^{\circ} 59^{\prime} \mathrm{N}\right.$ Lat. $18^{\circ} 35^{\prime} \mathrm{E}$ Long); $12.8 \mathrm{~m}$ level, $100 \mathrm{~m}$ from the sea. Sample from the exposed part of a partly buried log. This level is above the upper pumice level. Coll. 1957. Comment: this sample was surprisingly light. Two $\mathrm{C}^{13}$ determinations were made; $\delta=-7.8 \%$. 
U-36. Murchisonf jorden 5

$6490 \pm 110$

Wood from the north side of Søre Russøya $\left(79^{\circ} 58^{\prime} \mathrm{N}\right.$ Lat, $18^{\circ} 20^{\prime} \mathrm{E}$ Long) ; $8.8 \mathrm{~m}$ level, $75 \mathrm{~m}$ from the sea. Sample from the exposed part of a partly buried log. This level is the upper pumice level. Coll. 1957. Comment: $\delta=+0.3 \%$.

U-70. Murchisonf jorden 27

$9270 \pm 130$

Wood from a locality $1 \mathrm{~km} \mathrm{E}$ of Sveanor on the south shore of Murchisonfjorden $\left(79^{\circ} 56^{\prime} \mathrm{N}\right.$ Lat, $18^{\circ} 22^{\prime} \mathrm{E}$ Long); $36.5 \mathrm{~m}$ level, $500 \mathrm{~m}$ from the sea. Sample from the exposed part of a partly buried log. Coll. 1958. Comment: $\delta=+0.2 \%$.

U-37. Murchisonf jorden 6

$260 \pm 100$

Wood from the northeast side of Nordre Russøya $\left(80^{\circ} 0^{\prime} \mathrm{N}\right.$ Lat, $18^{\circ} 9^{\prime} \mathrm{E}$ Long) ; $1.8 \mathrm{~m}$ level, $10 \mathrm{~m}$ from the sea. Sample from a base timber (lying on the ground) of an old Russian trapping hut, which is most probably less than $250 \mathrm{yr}$ old. Coll. 1957. Comment: $\delta=+2.1 \%$.

U-35. Lady Franklinf jorden 4

$1775 \pm 80$

Wood from the valley parallel to and on the southwest side of Søre Franklinbreen $\left(80^{\circ} 5^{\prime} \mathrm{N}\right.$ Lat, $19^{\circ} 20^{\prime} \mathrm{E}$ Long $) ; 5.0 \mathrm{~m}$ level, $1000 \mathrm{~m}$ from the sea. Sample from a log lying loose on the surface, probably kicked by a reindeer, as it lay across the track of one. The place is a ground moraine flat between the glacier and its lateral moraine. Coll. 1957. Comment: $\delta=+0.3 \%$.

\section{U.71. Lady Franklinfjorden 30}

$\mathbf{3 6 , 0 0 0}+\mathbf{2 5 0 0}$

Shells from top of Teodolitkollen facing Søre Franklinbreen $\left(80^{\circ} 5^{\prime} \mathrm{N}\right.$ Lat, $19^{\circ} 20^{\prime} \mathrm{E}$ Long) ; $52 \mathrm{~m}$ level, $400 \mathrm{~m}$ from the sea. Shells in patterned ground (sorted circles in till) above shale bedrock, very nearly at the upper marine limit, where shells (mostly Saxicava arctica (L.)) occur. Coll. 1958. Comment: $\delta=+23.2 \%$.

\section{U-72. Lady Franklinf jorden 33}

$\mathbf{3 8 , 5 0 0}+\mathbf{3 5 0 0}$

Shells from the tundra south of Sevrinberget $\left(80^{\circ} 4^{\prime} \mathrm{N}\right.$ Lat, $19^{\circ} 10^{\prime} \mathrm{E}$ Long) ; $57 \mathrm{~m}$ level, $5 \mathrm{~km}$ from the sea. Shells in till above shale bedrock. These shells are the highest found in this area and are probably near the upper marine limit. Mostly Saxicava arctica (I.) . Coll. 1958. Comment: $\delta=+24.3$ \%o.

\section{1). Norwat}

\section{Vesteralen series}

Peat from Vesterålen, Nordlands fylke. These samples were taken to determine the variation in extent of the pre-recent local glaciation in the Scandinavian mountains. They were pretreated with $\mathrm{HCl}$ and cold $\mathrm{NaOH}$. Coll. and subm. by E. Bergström, Geografiska Institutet, Stockholms Högskola, Stockholm. 
U-59. Hadselфya 3

$4760 \pm 100$

Peat from Hadseløya $\left(68^{\circ} 33^{\prime} \mathrm{N}\right.$ Lat, $14^{\circ} 13^{\prime} \mathrm{E}$ Long $)$. The sample was taken $150 \mathrm{~cm}$ below the surface at the bottom of a bog situated inside a terminal moraine. Coll. 1955. Comment: $\delta=-1.9 \%$.

U-61. Hadselфya 5

$5180 \pm 100$

Peat from Hadseløya $\left(68^{\circ} 33^{\prime} \mathrm{N}\right.$ Lat, $14^{\circ} 13^{\prime} \mathrm{E}$ Long $)$. The sample was taken $340 \mathrm{~cm}$ below the surface at the bottom of a peat layer immediately above a moraine layer. Coll. 1955. Comment: $\delta=-4.3 \mathrm{c} / \mathrm{r}$.

U-62. And $\phi y a$ 6

Peat from Andøya $\left(68^{\circ} 53^{\prime} N\right.$ 1850 \pm 100 $68^{\circ} 53^{\prime} \mathrm{N}$ Lat, $15^{\circ} 28^{\prime} \mathrm{E}$ Long). The sample was taken $230 \mathrm{~cm}$ below the surface at the bottom of a peat layer, immediately above a moraine layer. Coll. 1957. Comment: $\delta=-3.3 \%$.

U-58. And $6 y$ a 2

$7600 \pm 130$

Peat from Andøya (68 $56^{\prime} \mathrm{N}$ Lat, $15^{\circ} 31^{\prime} \mathrm{E}$ Long). The sample was taken $270 \mathrm{~cm}$ below the surface at the bottom of a bog situated about $500 \mathrm{~m}$ inside a terminal moraine. Coll. 1957. Comment: $\delta=-4.6 \%$.

U-56. Andøya I A

$8880 \pm 130$ 370 . The sample was taken $370 \mathrm{~cm}$ below the surface in a sand layer underlying a bog, situated inside a terminal moraine. Coll. 1957. Comment: $\delta=+4.3 \%$.

U-60. Andøya 4

$7560 \pm 130$

Peat from Andøya $\left(69^{\circ} 5^{\prime} \mathrm{N}\right.$ Lat, $15^{\circ} 41^{\prime} \mathrm{E}$ Long). The sample was taken $400 \mathrm{~cm}$ below the surface in the same bog as sample U.56, but from the bottom layer of the bog and about $10 \mathrm{~m}$ from sample U-56. Coll. 1957. Comment: $\delta=$ $-4.1 \%$.

\section{E. Sweden}

\section{Samples of special palynologic interest}

\section{Varnhem series, Västergötland}

Gyttja from two cores (soil sampler, $38 \mathrm{~mm}$ diam) from the lakes Kroppsjön ( $58^{\circ} 23^{\prime} \mathrm{N}$ Lat, $13^{\circ} 37^{\prime} \mathrm{E}$ Long), and Spånsjön ( $58^{\circ} 23^{\prime} \mathrm{N}$ Lat, $13^{\circ} 36^{\prime} \mathrm{E}$ Long), N. Lundby parish, Västergötland, Sweden. The district is very calcareous and thus the groundwater may have influenced the $\mathrm{C}^{14}$ content in the lakes. Some of the sediments are due to algae and other submerged plants assimilating $\mathrm{CO} .2$ from the water, and some to plants assimilating $\mathrm{CO}_{2}$ from the air. At the higher levels the contribution from aquatic plants is smaller, and the corresponding dates should be more reliable. The pollen diagrams are discussed by Fries (1958). Coll. 1956 and subm. by Magnus Fries, Uppsala Iniversitels Västhiologiskal Institution.

\section{U-11. Lroppsjoin $A^{\text {o }}$}

$9870 \pm 110$

At or immediately below the beginning of the curve of Alnus glutinosa, pollen-analytic zone border V/VI (Jessen) ; 115.5 to $132 \mathrm{~cm}$ above the underlying till. Comment: $\delta=-8.6 \%$. Fromm (1938) gave another Swedish value for the age of this zone boundary, ca. $8250 \mathrm{yr}$, based on varve chronology

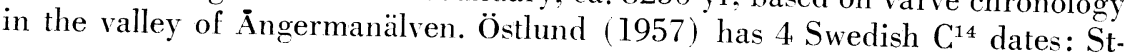


144, Adak, Malå parish, Västerbotten, $8575 \pm 120$; St-217, Degerfors, Närke, $8880 \pm 120 ;$ St-172, Hällesjö, Jämtland, $9100 \pm 120 ;$ St-173, Långared, Västergötland, $8500 \pm 110$. However, at least in the north of Sweden, the dates of St-144 and St-172, and probably Fromm's value also, probably refer to Alnus incana, not to A. glutinosa (Fries).

\section{U-12. Kroppsjön $\mathbf{U}^{-}$}

$5280 \pm 110$

At the decrease of the Ulmus curve, pollen-analytic zone border VII/VIII (Jessen) ; 538.5 to $545 \mathrm{~cm}$ above the underlying till. In Västergötland agriculture possibly began in the Early Neolithic phase A or B, here indicated by pollen of Triticum, Hordeum, and Plantago major. Finds of thin-butted flint axes probably imply agriculture during phase C. Comment: $\delta=-6.6 \%$. The date is in good agreement with U-14, U-16, U-17, U-27 (this date list), and with (1) Tauber's date, given by Brøndsted (1957) for the Ertebølle/ Ellerbek culture, Sartrup Moor, Schleswig, K-534, $5390 \pm 150$; (2) Willis' 3 dates, given by Godwin, Walker, and Willis (1957) for the minimum after the first decrease of Ulmus pollen, Scaleby Moss, Q-171, $4935 \pm 135 ;$ Q.172, $4990 \pm 120 ;$ Q-173, $4995 \pm 125$.

\section{U-13. Kroppsjön 3}

$3290 \pm 110$

At a maximum of the curve of Ulmus and an increase of the curve of Rumex acetosella, pollen-analytic zone VIII (Jessen) ; 687 to $695 \mathrm{~cm}$ above the underlying till. The increase may indicate expansion of tilled areas and pastures in the Late Neolithic period or the beginning of the Bronze age. Comment $: \delta=-8.3 \%$.

\section{U-14. Spånsjön $\mathbf{U}^{-}$}

At the decrease of the Ulmus curve, pollen-analytic zone border VII/VIII (Jessen) ; 126.5 to $130 \mathrm{~cm}$ above the underlying till. Comment: $\delta=-4.8 \% \mathrm{cc}$. A comparison with similar samples is given under U-12.

\section{Mogetorp series, Södermanland}

Sediments and wood from Övre Mogetorp Moss $\left(59^{\circ} 0^{\prime} \mathrm{N}\right.$ Lat, $16^{\circ} 9^{\prime} \mathrm{E}$ Long), Södermanland, Sweden. The samples were taken with a Hiller sampler. Two levels indicating Neolithic agriculture have been determined. The pollen analysis has been done and the locality is described by Maj-Britt Florin (1957) . The moss is a small raised bog, $50 \mathrm{~m}$ above sealevel. The sediments are freshwater deposits. Coll. 1943 and subm. by Sten Florin, Uppsala Universitets Mineralogisk-Geologiska Institutions Kvartärgeologiska avdelning. Comment: A comparison with similar samples is given under U-12.

\section{U-16. Mogetorp C I}

$5330 \pm 100$

Lake dy from a level immediately below the zone border VII/VIII (Jessen) (bolow the beginning of the decrease of the Cllmus curve); 24 ('m lower in the sequence than samples $\mathrm{U} .17$ and U.27. Comment: $\delta=-3.4 \mathrm{~K}$.

\section{U-17. Mogetorp C II w}

$5360 \pm 100$

Small wood (Betula) remains in the lower parts of limnic or telmatic peat from a level immediately above the zone border VII/VIII (Jessen) (above the decrease of the Ulmus curve). Comment: $\delta=-3.4 \%$. 
U-27. Mogetorp C II p

The peat remaining when the wood for sample U-17 had been selected. Comment: $\delta=-4.6 \%$.

\section{Sealevel changes and strandlines}

\section{Littorina series, Södermanland}

Algal mud from Bygdslätten (58 $531 / 2^{\prime}$ N Lat, $16^{\circ} 18^{\prime}$ E Long), Björkvik parish, and Källtorp ( $59^{\circ} 51 / 2^{\prime} N$ Lat, $16^{\circ} 8^{\prime} \mathrm{E}$ Long), Julita parish, Södermanland, Sweden, dating the first Littorina maximum, LI (Littorina-Tapes maximum), which probably is contemporaneous with the maximum of the full Atlantic transgression in Denmark. Round axes, which are typical for the maximum, LI, have been found at the localities investigated. All settlements have been limited by the coastline. The water may have been stagnant in coastal lagoons, and some of it may have passed calcareous layers, thus causing toohigh ages of the algae. The sediments are covered with peat, the upper part of which is cultivated. The localities were investigated and described by Sten Florin (1947, 1958, 1959) and Maj-Britt Florin (1946).

\section{U-43. Bygdslätten $\mathbf{G}$}

$6980 \pm 120$

Green algal mud, 90 to $95 \mathrm{~cm}$ below the surface, which is $48.6 \mathrm{~m}$ above sealevel. The highest Littorina limit is about $49.5 \mathrm{~m}$ above sealevel. Brackishwater sediment containing Clypeus. The overlying red gyttja also contains Chroococcaceae. Coll. 1935 and subm. by Sten and Maj-Britt Florin, Uppsala Universitets Mineralogisk-Geologiska Institutions Kvartärgeologiska avdelning. Comment: $\delta=+4.3 \%$.

\section{U-41. Bygdslätten $R$}

$6830 \pm 120$

Red algal mud, 70 to $75 \mathrm{~cm}$ below the surface, overlying sample U-43. Coll. 1935 and subm. by Sten and Maj-Britt Florin, Uppsala Universitets Mineralogisk-Geologiska Institutions Kvartärgeologiska avdelning. Comment: $\delta=$ $-2.6 \%$.

\section{U-42. Källtorp $\mathbf{G}$}

$6950 \pm 130$

Green algal mud, 60 to $65 \mathrm{~cm}$ below the surface, which is $52 \mathrm{~m}$ above sealevel. The highest Littorina limit is about $54 \mathrm{~m}$ above sealevel. Brackishwater sediment. Coll. 1934 and subm. by Sten and Maj-Britt Florin, Uppsala Universitets Mineralogisk-Geologiska Institutions Kvartärgeologiska avdelning. Comment: $\delta=-8.1 \%$.

\section{U-11. Ösäter}

Charcoal from Ösäter $\left(55^{\circ} 5512^{\prime} \mathrm{N}\right.$ Lat, $17^{\circ} 10^{\prime} \mathrm{E}$ Long $)$, Ludgo parish, found in postglacial clay, 50 to $60 \mathrm{~cm}$ below the surface. The charcoal constitutes a distinct horizon in the sterile postglacial drift-clay (an allochthonous formation, not contemporaneous with the stone artifacts. Coll. $48 \mathrm{~m}$ above sealevel. The phosphate analysis at the level of the charcoal showed a distinct change from a high to a low content of $\mathrm{P}_{2} \mathrm{O}_{5}$. The round axes can be related to some axes from Mogetorp. Coll. 1956 and subm. by Sten Florin, Uppsala Universitets Mineralogisk-Geologiska Institutions Krartärgeologiska avdelning. Comment: This sample was pretreated in Stockholm as S-171 and delivered to Uppsala as a carbonate. $\delta=-1.4 \%$. 
3. Various geologic samples

U-51. Mossberga Mose

$\mathbf{3 1 9 0} \pm \mathbf{7 0}$

Plant detritus filling the brain cavity of a subfossil stag, Cervus elaphus (L.), from Mossberga Mose (56 $46^{\prime} \mathrm{N}$ Long, $16^{\circ} 36^{\prime} \mathrm{E}$ Lat), Högsrum parish, Öland, Sweden. It was found in a semi-liquid detritus-gyttja, underlain by lime-gyttja. The sample contains remains of e.g. Salix, Carex, Chara, scattered gastropods and lamellibranchs (Bithynia, Valvata, Pisidum). Pollen analysis indicates the sample to be older than the immigration of Picea and Fagus in the south of Sweden. Coll. 1917 by E. Bergquist; subm. by A. Martinsson, Uppsala Universitets Paleontologiska Institution. Comment: outer parts of the samples were removed. $\delta=-3.5 \%$.

U-15. Västerhejde

$1660 \pm 100$

Charcoal (Pinus) in sandy soil, beneath a 60 -cm-thick layer of raw humus at Västerhejde $\left(57^{\circ} 34^{\prime}\right.$ N Lat, $18^{\circ} 15^{\prime}$ E Long), Gotland, Sweden. The ground is now covered by Pinus silvestris and Calluna vulgaris. In Gotland one can find a lot of charcoal, sometimes together with artifacts, in the upper layers of marshes and in woodland. This sample was the first in a planned investigation of these localities. Coll. 1957 and subm. by B. Pettersson, Uppsala Universitets Växtbiologiska Institution. Comment: $\delta=-0.7 \%$.

\section{U-26. Visingsö}

$535 \pm 70$

Charcoal together with slag from Bengtsgården $\left(58^{\circ} 18^{\prime} \mathrm{N}\right.$ Lat, $14^{\circ} \mathrm{I}^{\prime} \mathrm{E}$ Long), western shore of the island Visingsö in the lake Vättern, Sweden. Found on sand of the upper beach and overlain by about $1 \mathrm{~m}$ morainic talus (clay). The sample was taken about $1 \mathrm{~m}$ inside a re-entrant in a recently wave-cut escarpment. The intention was to measure the erosion rate. Estimated from postglacial land uplift to be younger than $900 \mathrm{yr}$. Coll. 1957 and subm. by J. Norrman, Uppsala Universitets Geografiska Institution. Comment: $\delta=-1.1$ $\%$.

\section{U-55. Tönnersa}

$1370 \pm 70$

Sandy soil from Tönnersa $\left(56^{\circ} 35^{\prime}\right.$ N Lat, $12^{\circ} 581 / 2^{\prime}$ E Long), Halland, Sweden. Sample at about $25 \mathrm{~cm}$ below the surface in a layer with humus accumulation ( 5 to $6 \%$ humus). In the same layer but not in sample U-55 there was charcoal from a time when the vegetation was burnt. The date of the fire is probably that of the sample; the upper $25 \mathrm{~cm}$ of the profile was subsequently deposited by wind and is now cultivated. The sample was taken as a part of a crop-rotation experiment. Coll. 1957 and subm. by S. Odén, Institutionen för Marklära, Lantbrukshögskolan, Uppsala. Comment: pretreatment: $\mathrm{HCl}$ and cold $\mathrm{NaOH} . \delta=-3.7 \%$.

\section{ARCHAEOLOGIC SAMPLES}

\section{A. India}

\section{Rang Mahal series}

Charcoal and bone from Rang Mahal ( $29^{\circ} 21^{\prime} \mathrm{N}$ Lat, $73^{\circ} 57^{\prime} \mathrm{E}$ Long), Rajputana, India. The complex is described by Rydh and others (in press). Subm. by K. G. Eriksson, Uppsala Universitets Mineralogisk-Geologiska In- 
stitutions Kvartärgeologiska avdelning. Comment: one sample from this series has previously been determined by Östlund (1957), St-192, $1525 \pm 70$.

U.1. RM I:A 12

$1810 \pm 120$

Charcoal found in clay and sand together with artifacts, $3.6 \mathrm{~m}$ below the highest level of the site. The charcoal is assumed to come from a fireplace. Associated ceramics indicate an age of 1500 to 2000 yr. Coll. 1953 by H. Arbman, Lunds Universitets Historiska Museum. Comment: diluted. $\delta=+1.2 \%$.

U-52. RM II 4

$1480 \pm 70$

Charcoal found in clay and sand together with artifacts, $0.5 \mathrm{~m}$ below the surface. The charcoal is assumed to come from a fireplace. Coll. 1953 by Hanna Rydh. Comment: $\delta=+1.0 \%$.

U-24. RM II 15 o

$760 \pm 100$

Organic fraction of bones of a camel found $2 \mathrm{~m}$ below the surface. Associated ceramics indicate an age of 1500 to 2000 yr. Coll. 1953 by Hanna Rydh. Comment: comparison with sample U.23 shows that these two dates must be rejected. $\delta=+4.6 \%$.

U-23. RM II 15 oo

$1570 \pm 150$

Inorganic fraction of the bones used for sample U-24. Comment: diluted. $\delta=+29.7 \%$.

\section{B. Egypt}

\section{U-5. Abu Ghalib}

$3370 \pm 240$

Charred grains from Abu Chalib, IIId $3\left(30^{\circ} 15^{\prime} \mathrm{N}\right.$ Lat, $30^{\circ} 56^{\prime} \mathrm{E}$ Long), Egypt, $25 \mathrm{~cm}$ below the clay surface. The clay is covered by $1.5 \mathrm{~m}$ of sand. The age was supposed to be almost 4000 yr. Described by Larsen (1935, 1941). Coll. 1937 by the Swedish Egypt Expedition; subm. by T. SäveSöderbergh, Uppsala Universitets Egyptologiska Institution. Comment: diluted.

\section{U-4. Ma'sara 6}

$3840 \pm 150$

Charred grains in a big vessel from tomb 6, Ma'sara $\left(29^{\circ} 54^{\prime} \mathrm{N} \mathrm{Lat,} 31^{\circ}\right.$ $18^{\prime} \mathrm{E}$ Long), Egypt. The age is regarded as $4760 \pm 100$ (II dyn.) Described by Larsen (1940). Coll. 1937 by H. Larsen, Egyptiska Avdelningen, Medelhavsmuseet, Stockholm; subm. by T. Säve-Söderbergh, Uppsala Universitets Egyptologiska Institution. Comment: diluted.

\section{Merimde series}

Charred grain, charcoal, and bone from Merimde $\left(30^{\circ} 19^{\prime} \mathrm{N}\right.$ Lat, $30^{\circ} 50^{\prime}$ E Long), Egypt. The culture layers (an old, a transition, and a young period) are usually supposed to be of the same age (upper layers) or older than Fayum A, which is estimated to be about $7000 \mathrm{yr}$ old (Caton-Thompson). Merimde has also been compared with Negada II, (Baumgartel), about 5000 yr. Oldest period of Negada II is assumed to be about $300 \mathrm{yr}$ older than Ma'sara tomb 6 . Merimde is rich in artifacts. Described by Larsen (in press). Coll. 1931 and 1932 by the Austrian Egypt Expedition; subm. by T. Säve-Söderbergh, Uppsala Universitets Egyptologiska Institution. 


\section{U-10. Merimde T 4}

Charred grains, $60 \mathrm{~cm}$ below surface. Comment: pretreatment: $\mathrm{HCl}$.

U-73. Merimde T 4

$5640 \pm 100$

The same as U-10, new combustion. Comment: $\delta=0.0 \%$. Pretreatment: $\mathrm{HCI}$ and $\mathrm{NaOH}$.

U-6. Merimde 180

$$
6130 \pm 110
$$

Charcoal, $180 \mathrm{~cm}$ below the surface.

U.7. Merimde R 1

$5700 \pm 700$

Charred grains, $180 \mathrm{~cm}$ below the surface. Comment: diluted.

U.32. Merimde T 4 o

$4560 \pm 140$

Organic fraction of bones from hippopotamus, $180 \mathrm{~cm}$ below the surface. Comment: The difference between sample $\mathrm{U}-32$ and $\mathrm{U}-31$ is too large. The bones must have been contaminated. $\delta=+4.0 \%$.

U-31. Merimde T 4 oo $\quad 3630 \pm 100$

Inorganic fraction of the same bones as U.32. Comment: $\delta=+16.8 \%$.

U-8. Merimde A 18

$\mathbf{5 5 8 0} \pm \mathbf{2 3 0}$

Charred grains, depth not known. Comment: diluted.

U.9. Merimde Tamarix

$5970 \pm 120$

$5940 \pm 100$

Charcoal, depth not known but less than $180 \mathrm{~cm}$.

\section{Sweden}

\section{Vätteryd series, Skåne}

Charcoal from Vätteryd $\left(56^{\circ} 1^{\prime}\right.$ N Lat, $13^{\circ} 3912^{\prime}$ E Long), N. Mellby parish, Sweden. The culture layer, $20 \mathrm{~cm}$ thick, contains sherds from the Early Neolithic period. The settlement corresponds to a level immediately above the pollen-analytic zone border $\mathrm{IV}^{\mathrm{s}} / \mathrm{V}^{\mathrm{s}}$ (Tage Nilsson) according to Ingeborg Tilander (1958). The site is described by Petré and Strömberg (1958). Coll. 1957 by R. Petré and subm. by H. Arbman, Lunds Universitets Historiska Museum.

U-46. Vätteryd 1

$4555 \pm 140$

Charcoal from the whole layer. Comment: diluted. $\delta=-1.9 \%$.

\section{U-47. Vätteryd 2}

$4690 \pm 170$

Charcoal from the bottom of the layer. Comment: diluted. $\delta=-2.9 \%$.

\section{U-48. Elinelund 71}

$5320 \pm 210$

Charcoal and hazel-nut shells from Elinelund $\left(55^{\circ} 34^{\prime} \mathrm{N}\right.$ Lat, $12^{\circ} 55^{\prime} \mathrm{E}$ Long), outside Malmö, Skåne, Sweden. The culture layer, 20 to $30 \mathrm{~cm}$ thick, contains pottery of Ertebølle type and a few sherds of Early Neolithic type. The locality is described by Althin (1954). Coll. (1957) by B. Salomonsson and subm. by H. Arbman, Lunds Universitets Historiska Museum. Comment: diluted. $\delta=-2.9 \%$. 
U-49. Simris no. $2: 43$

Charcoal from grave 43 at Simris $\left(55^{\circ} 32^{\prime} \mathrm{N}\right.$ Lat, $13^{\circ} 19^{\prime} \mathrm{E}$ Long $)$, Skåne, Sweden. Of four urn burials inside a stone circle two are dated by a razor to the fifth period of the Bronze Age (Montelius' system), and the other two may perhaps be younger (fifth or sixth period). The sample was found adjacent to the stones of the circle, $50 \mathrm{~cm}$ below the surface. Coll. 1950 and subm. by Bertha Stjernquist, Lunds Universitets Historiska Museum. Comment: $\delta=$ $-3.0 \%$. Some resin from a grave from the fourth period, subm. by Oldeberg, has been dated by Östlund (1957): St-201, $2810 \pm 75$.

\section{Darsgärde series, Uppland}

Charcoal from an ancient site at Darsgärde $\left(59^{\circ} 43^{\prime} \mathrm{N}\right.$ Lat, $18^{\circ} 2912^{\prime} \mathrm{E}$ Long), Skederid parish, Uppland, Sweden. The complex includes grave-fields as well as an ancient hill-fort. The fort, its surrounding wall with a gate, and its buildings seem to belong to the middle of the Iron Age. The coastline of that time seems to have been 7 or $8 \mathrm{~m}$ higher than now. The complex is described in a preliminary report by Ambrosiani (1958). Coll. and subm. by B. Ambrosiani, Uppsala Universitets Institution för Nordisk och Jämförande Fornkunskap.

U-18. Darsgärde A 4

$1640 \pm 80$

Charcoal from the tower above the gate, probably from the second period of the wall. Found under one of the stones that had been put there after the wooden construction had been burnt. Comment: $\delta=+0.5 \%$.

U-19. Darsgärde wall

$1640 \pm 70$

Charcoal from the oldest layer of the wall, supposed to consist of wooden cists filled with earth. After this wooden construction had been burnt, a second and then a third layer were built. The layers are separated by horizons with charcoal and soot. Comment: $\delta=-0.8 \%$.

\section{U-53. Västerby $5^{\prime}: 9$}

$390 \pm 90$

Charcoal, about $10 \mathrm{~cm}$ depth, from Västerby $\left(59^{\circ} 51^{\prime} \mathrm{N}\right.$ Lat, $17^{\circ} 31^{\prime} \mathrm{E}$ Long), Läby parish, Uppland, Sweden. Site 9 consists of an almost circular stone construction around a boulder. Above the charcoal layer there were stones, bones, and pieces of prehistoric pottery with a pronounced out-turned rim. In the neighborhood, however, glazed pottery about $200 \mathrm{yr}$ old was found, as were some recent iron objects. The site does not seem to have been intact. The complex is described by Hagberg (1959). Coll. 1957 and subm. by U. E. Hagberg, Uppsala Universitets Institution för Nordisk och Jämförande Fornkunskap. Comment: $\delta=-0.6 \% / \mathrm{c}$.

\section{U-67. Skyttorp boat}

$975 \pm 70$

Wood from a boat found in the bog Örsmossen $\left(60^{\circ} 412^{\prime} \mathrm{N}\right.$ Lat, $17^{\circ}$ $421 / 2^{\prime}$ E Long), Skyttorp, Tensta parish, Uppland, Sweden. The boat, length about $3.5 \mathrm{~m}$, was made by gouging a coniferous tree. Subm. by Uppsala Universitets Institution för Nordisk och Jämförande Forkunskap. Comment: $\delta=$ $-0.6 \%$.

U-50. Västeråker axe

$2330 \pm 90$

Wood from the handle of a socketed bronze axe from Torresta $\left(59^{\circ} 46^{\prime} \mathrm{N}\right.$ 
Lat, $17^{\circ} 30^{\prime} \mathrm{E}$ Long), Västeråker parish, Uppland, Sweden. Part of the handle was still left in the cavity of the axe. It was detected during tilling of a field, which previously was the bottom of a lake, and $75 \mathrm{yr}$ ago was a boggy ground. Coll. by V. Ericsson; subm. by Uppsala Universitets Institution för Nordisk och Jämförande Fornkunskap. Comment: $\delta=-2.1 \%$.

\section{U-66. Svarvarbo plough}

$840 \pm 70$

Wood from a stick found in a bog at Svarvarbo $\left(60^{\circ} 1 / 2^{\prime} \mathrm{N}\right.$ Lat, $17^{\circ} 24^{\prime}$

E Long), Skuttunge parish, Uppland, Sweden. The shape is roughly a V, with an angle of about $145^{\circ}$ between the legs. The wood is oak, well preserved, and there is no doubt that it was finally shaped by man. The manner in which this stick may have been used as part of a plough has been discussed by Larsen (1925, 1929, 1931), Leser (1925), and Jirlow (1935). It was found lying horizontally in wet, mellow clay immediately below the boundary between the clay and the overlying bog. A pollen-analytic investigation of the bog (Granlund) shows that the plough belongs to the Bronze Age, if the location of the stick was exactly determined and if it was contemporaneous with the plough. Coll. 1911 by J. Mattsson and his sons when ditching the bog; subm. by Uppsala Universitets Institution för Nordisk och Jämförande Fornskunskap. Comment: $\delta=-1.4 \%$.

\section{U-45. Björnlunda plough}

$1125 \pm 70$

Wood from a plough found $500 \mathrm{~m} \mathrm{E}$ of Tibble gård $\left(59^{\circ} 6^{\prime} \mathrm{N}\right.$ Lat, $17^{\circ}$ 8' E Long), Björnlunda parish, Södermanland, Sweden. The plough was detected $20 \mathrm{~cm}$ below the surface in muddy soil during tilling. Subm. by Uppsala Universitets Institution för Nordisk och Jämförande Fornkunskap. Comment: $\delta=-2.4 \%$. Wood from the plough was subm. by N.-G. Gejvall, Statens Historiska Museum, Stockholm, to the Stockholm laboratory: Östlund (1959), St-372, $1185 \pm 70$.

\section{INDUSTRIAL SAMPLE}

\section{U-40. Östrand 1}

$85.7 \pm 1.0 \%$ recent carbon

Incrustation from a boiler of the Östrand factories, Svenska Cellulosa A/B. At the request of Mellersta och Norra Sveriges Angpanneförening, the content of organic carbon in the crust, which could be derived either from cellulose or from petroleum, or from both, was determined. Subm. by L. Arnbom. Comment: the result given is calculated using the Uppsala reference sample corrected for age but not for the Suess effect (Suess, 1955) or for the atomic bomb effect. The age of the wood burned in the boiler is not known. $\delta=-2.8 \%$.

\section{ATOMIC BOMB EFFECT}

All values are related to the Uppsala reference sample corrected only for decay due to age. The results give the excess in percent over the corrected reference sample.

U.29. Bones 57 o

Organic fraction from a bone of a pig which had grown in Sweden in 
1957. Comment: this bone was treated to give experience with bone. The $\mathrm{C}^{1+}$ activity was measured as a check of the two fractions. $\delta=-1.4 \%$.

U-28. Bones 57 oo $+6.7 \%$.

Inorganic fraction from the bone used for sample U-29. Comment: $\delta=$

\section{U-65. Typha 57}

Typha latifolia from Ekensherg $\left(59^{\circ} 481 / \mathbf{1 0 . 2} \pm \mathbf{0 . 8 \%}\right.$

Uppsala, Sweden. The plant was othered

Uppsala, Sweden. The plant was gathered about August 1, 1957 by the author.

Comment: $\delta=-2.7 \%$.

V. CROSS-CHECK SAMPLES
U-20, and
U-75.
Ruds Vedby
$10,830 \pm 130$
$10,680 \pm 130$

Wood from Ruds Vedby (55 $32^{\prime} \mathrm{N}$ Lat, $11^{\circ} 22^{\prime}$ E Long), Sjaelland, Denmark. The wood was collected at the zone border Allerød/Younger Dryas. Subm. by H. Tauber. Comment: $\delta=-2.6 \%$. Wood of the same origin has been dated by others: Anderson, Levi, and Tauber (1953), K-101, 10,890 \pm 240 (solid carbon); Suess (1954), W-82, 10,260 \pm 200 ; W-84, 10,510 \pm 180; Münnich (1957b), H-105-87, 11,500 \pm 300 ; Östlund (1957), St-18, $10,200 \pm 300$ (solid carbon), Barker and Mackey (1959), BM-19, 11,333 \pm 200.

U-68. Lago di Nemi

Wood from Roman ships at $1980 \pm 70$ Italy. The ships are attributed to the Nemi $\left(41^{\circ} 43^{\prime} \mathrm{N}\right.$ Lat, $1^{\circ} 34^{\prime} \mathrm{E}$ Long), by C. Cortesi and F. 37 to 41). Subm. by C. Cortesi and F. Bella, Carbon-14 laboratory, Rome. Comment: $\delta=+0.1$ $\%$. Wood of the same origin has been dated by others: Ballario and others (1955), $2030 \pm 200$ (solid carbon); Nydal and Sigmond (1957), T-9, 1880 \pm 130 ; Östlund (1957), St-103, $2010 \pm 65$; Barker and Mackey (1959), BM-15, $2080 \pm 150$; Godwin and Willis (1959). Q-112. $1904 \pm 95$.

\section{U-69. St. Walburgkerk}

Wood from a church at Groningen $1095 \pm 70$ Netherlands. Subm. by Hl. de Vries, Univerity $12^{\prime} \mathrm{N}$ Lat, $6^{\circ} 36^{\prime} \mathrm{E}$ Long), $-2.9 \%$. Wood of the same origin has been of Groningen. Comment: $\delta=$ Barendsen (1954) Barendsen (1954), mean value $980 \pm 50$; Tauber (private communication), K-143, $1180 \pm 120$; Nydal and Sigmond (1957), T-29, $1050 \pm 100$; Münnich (1957b), H-8-7, $1245 \pm 130$; Shutler and Damon (1959), A-81A, $925 \pm$ 230 and A-81B, $870 \pm 110$; Olson and Broecker (1959), L-292, $1250 \pm 150$.

\section{$\begin{array}{lll}\text { U-57. Heidelberg labeled reference sample } & 10.373 \pm 0.040 & x \\ \text { U-76. } & \end{array}$ $10.336 \pm 0.040 \times$}

Labeled sample distributed by K. O. Münnich. The result given is the ratio between the activity of this sample and the Uppsala reference sample, corrected for decay due to age. U-57 corresponds to measurements made in the spring of 1958; U-76 to measurements made during the autumn of 1958. 
REFERENCES

Althin, C. A., 1954, The chronology of the stone age settlement of Scania, Sweden I. The mesolithic settlement: Acta Archaeologica Lundensia, ser. in $4^{\circ}$, no. 1,311 p.

Ambrosiani, B., 1958, Darsgärdekomplexet: Fornvännen, v. 53, p. 161-176. 1959, Keramikboplatsen på Hamnbrinken vid Darsgärde: Tor, v. 5, p. 108-128. Anderson, E. C., Levi, H., and Tauber, H., 1953, Copenhagen natural radiocarbon measurements, I: Science, v. 118, p. 6-9.

Ballario, C Beneventano, M., de Marco, A., Magistrelli, F., Cortesi, C., and Mantovani, T., 1955, Apparatus for carbon-14 dating: Science v. 121, p. 409-412.

Barendsen, G. W., 1955, Ouderdomsbepaling met radioactieve koolstof: Doctoral diss., Univ of Groningen, $88 \mathrm{p}$.

Barker, H., and Mackey, C. J., 1959, British Museum natural radiocarbon measurements I: Am. Jour. Sci. Radioc. Supp., v. 1, p. 81-86.

Brøndsted, J., 1957, Danmarks Oldtid. Vol. I. Stenalderen: København, Gyldendal, Nordisk

Forlag A/S, 408 p.
Craig. Harmon, 1953 , The geochemistry of the stable carbon isotopes: Geochim. et Cosmochim. Acta, v. 3, p. 53-92.

1954, Carbon 13 in plants and the relationships between carbon 13 and carbon 14. variations in nature: Jour. Geology, v. 62, p. 115-149.

Florin, Maj-Britt, 1957, Pollen-analytical evidence of prehistoric agriculture at Mogetorp Neolithic settlement, Sweden, in Florin, Sten, ed., Vråkulturen [1958]: Stockholm, Kungl. Vitterhets Historie och Antikvitets Akademiens Monografiserie, p. 221-247. Kungl. Vitterhets Historie och Antikiala fornsjölagerföljder i östra Mellan-Sverige: Geol. fören. Stockholm förh., v. 68, p. 429-458.

Florin, Sten, 1947, Nivåförändringarna i Kolmården under äldre litorinatid: Geol. fören. Stockholm förh., v. 69, p. 337-359.

Stockholm forh., v. 69, p. 337-359. under senkvartär tid. II. De baltiska strandbildningarna och stenåldersboplatsen vid Dammstugan nära Katrineholm: Geol. fören. Stockholm förh., v. 70, p. 17-196. Dammstugan nära Katrineholm: Geol. loren. Svartsförande făngstboplats från tidig litorinatid: Tor, v. 5, p. 7-51.

Fromm, Erik, 1938, Geochronologisch datierte Pollendiagramme und Diatoméenanalysen aus Ängermanland: Geol. fören. Stockholm förh., v. 60, p. 365-381.

Fries, Magnus, 1958, Vegetationsutveckling och odlingshistoria i Varnhemstrakten: Acta Phytogeographica Suecica, v. 39, p. 1-64.

Codwin H. Walker, D., and Willis, E. H., 1957, Radiocarbon dating and post-glacial vegetational history: Scaleby Moss: Royal Soc. [London] Proc., ser. B, v. 147, p. 352 366 .

Godwin, H., and Willis, E. H., 1959, Cambridge University natural radiocarbon measurements I: Am. Jour. Sci. Radioc. SuPP., v. 1, p. 63-75.

Hagberg, U. E., 1959, Västerby gravbacke i Läbydalen: Tor, v. 5, p. 172-191.

Harlow, R., 1935, Plogkroken från Svarvarbo och några andra förhistoriska plogar: Upplands fornminnesförenings tidskr., v. 45, supp. 1, p. 1-22.

Jónsson, Jón, 1957, The Hoffellssandur. Notes on changes of sea-level on Iceland: Geog. Annaler, v. 39, p. 143-212.

Kyrle, G., 1946 and 1947, Le grotte dell'Isola di Capri: L'Universo, v. 26, p. 57-109; v. 27, p. $17-47 ; 141-160$

Larsen, H., 1925, Ein steinzeitlicher Pflug aus Schweden: Die Umschau, v. 29 , p. 95.

1929, Bronsåldersplogen från Svarvarbo: Fornvännen, v. 24, p. 177-180.

1931, Plogen från Svarvarbo: Upplands fornminnesförenings tidskr., v. 43, p. $81-96$

1935, Vorbericht über die schwedischen Grabungen in Abu Ghalib 1932-1934: Deutsche Inst. Ägypt. Altertumskunde in Kairo Mitt., v. 6, p. 41-87.

1940. Tomb Six at Maassara, an Egyptian second dynasty tomb: Acta Archaeologica, v. 11, p. 103-124.

1941, Vorbericht über die schwedischen Grabungen in Abu

Deutsche Inst. Ägypt. Altertumskunde in Kairo Mitt., v. 10, p. 1-59. in press, Verzierte Tongefäss-scherben aus Merimde, Benisalane in der Ägyptischen Abteilung des Mittelmeersmuseums in Stockholm: Orientalia Suecana, v. 7.

Leser, P., 1925, Ein Pflug aus der Steinzeit?: Anthropos, v. 20, p. 740-744.

676 p.
Münnich, K. O., 1957a, Messungen des C 14-Gehaltes von hartem Grundwasser: Naturwissenschaften, v. 44 , p. $32-33$ 
199.

1957b, Heidelberg natural radiocarbon measurements I: Science, v. 126, p. 194-

Norin, Erik, 1958a, Die Sedimente des Zentralen Tyrrhenischen Meeres: Geol. Rundschau, v. 47 , p. $207-218$.

1947-1948 1958b, Sediment cores from the Mediterranean Sea: Swedish Deep-Sea Exped. Nydal, Reidar, and Sigmond, R. S., 1957, Radiocarbon dating in Trondheim: Appl. Sci.
Res., sec. B, v. 6, p. 393-400.

Olson, E. A., and Broecker, W. S., 1959, Lamont natural radiocarbon measurements V: Am. Jour. Sci. Radioc. Supp., v. l, p. 1-28.

Olsson, Ingrid, 1958, A C $\mathrm{C}^{14}$ dating station using the $\mathrm{CO}_{2}$ proportional counting method: Arkiv för Fysik, v. 13, p. 37-60.

Östlund, H. G., 1957, Stockholm natural radiocarbon measurements I: Science v 126, p. 493-497. Supp., v. 1, p.

Hörstad Strömberg, M., 1958, Prehistoric and mediaeval settlement sites at Råga Hörstad, Asmundtorp: Lunds Univ. Hist. Mus. Medd., p. 52-90.

Petterson, B., 1958, Dynamik och konstans i Gotlands flora och vegetation: Acta Phytogeographica Suecica, v. 40, p. 30-31

Revelle, Roger, and Suess, H. E., 1957, Carbon dioxide exchange between atmosphere and ocean and the question of an increase of atmospheric $\mathrm{CO}_{2}$ during the past decades:
Tellus, v. 9, p. 18-27. Rubin, Meyer, and Alexander, Corrinne, 1958, U. S. Geological Survey radiocarbon dates
IV: Science, v. 127, p. 1476-1487.

Rubin, Meyer, and Suess, H. E., 1955, U. S. Geological Survey radiocarbon dates II: Science, v. 121 , p. $481-488$.

Rydh, H., and others, in press, Rang Mahal: The Swedish archaeological expedition to India, 1952-1953: Acta Archaeologica Lundensia, ser. in $4^{\circ}$, no. 3.

Shutler, Dick, Jr., and Damon, P. E., University of Arizona radiocarbon dates II: AM. Jour. Sci. Radioc. Supp., v. l, p. Suess, H. E., 1954, U. S. Geological Survey radiocarbon dates I: Science, v. 120 , p. 467.
473.

Thorarins 1955, Radiocarbon concentration in modern wood: Science, v. 122, p. 415-417. gurinn, v. 25, p. 148-153.

Thorddsen, Th, 1925 , Die Selsk. Skr., ser. 8, v. 9, p. 1-458. lander, I., 1958, Pollen-analytical investigation of two prehistoric layers at Vätteryd:
Lunds Univ. Hist. Mus. Medd., p. 91-102.

Vries, Hl. de, 1958, Variation in concentration of radiocarbon with time and location on Earth: Koninkl. Nederlandse Akad. Wetenschappen Proc., ser. B., v. 61, no. 2, p. 1-9.

Vries, Hl. de, and Barendsen, G. W., 1954, Measurements of age by the carbon-14 technique: Nature, v. 174, p. 1138-1141.

Vries, Hl. de, Barendsen, G. W., and Waterbolk, H. T., 1958, Groningen radiocarbon dates II: Science, v. 127, p. 129-137.

Wickman, F. E., 1952, Variations in the relative abundance of the carbon isotopes in plants: Geochim. et Cosmochim. Acta, v. 2, p. 243-254. 